\title{
Hydrogeochemical characteristics and assessment of water quality in the Al-Saad Lake, Abha Saudi Arabia
}

\author{
Javed Mallick ${ }^{1}$
}

Received: 20 May 2015/Accepted: 1 March 2017/Published online: 18 March 2017

(c) The Author(s) 2017. This article is an open access publication

\begin{abstract}
Hydrogeochemical characteristics and assessment of water quality investigations have been carried out at Abha, located in Saudi Arabia, where Al-Saad Lake represents a rare example of natural endorheic lake. The ecosystem within and around the Al-Saad Lake including catchment area is of great social, cultural, aesthetic, environmental and economic values to Abha. Sampling and experiments of lake water has been carried out with the aim of characterizing the main physico-chemical parameters, such as DO, EC, TDS, $\mathrm{Mg}^{2+}, \mathrm{Ca}^{2+}, \mathrm{Na}^{+}, \mathrm{K}^{+}, \mathrm{SO}_{4}{ }^{2-}, \mathrm{Cl}^{-}$, $\mathrm{HCO}_{3}, \mathrm{NO}_{3}{ }^{-}$and $\mathrm{F}^{-}$concentration. The ordinary kriging (OK) method was used to produce the spatial patterns of water quality. The Result of DO (mean $5.38 \mathrm{mg} / \mathrm{L}$ ) trend in Al-Saad Lake is not very encouraging as majority of the lake area is under DO stress or marginally above it. So, proper management strategies are needed to be formulated to protect flora and fauna of the lake. Furthermore, the chemical analysis results show the abundance of the major cations in the order $\mathrm{Mg}^{2+}>\mathrm{Ca}^{2+}>\mathrm{Na}^{+}>\mathrm{K}^{+}$whereas the abundance of anions are in the order $\mathrm{SO}_{4}{ }^{2-}>$ $\mathrm{Cl}^{-}>\mathrm{HCO}_{3}>\mathrm{NO}_{3}{ }^{-}>\mathrm{F}^{-}$. The result obtained in this investigation inferred that the cations in water i.e. sodium and iron are within the permissible limits but magnesium and potassium have exceeded the permissible limit. Whereas anions such as nitrate and fluoride are within the permissible range but chloride and sulphate have exceeded the permissible limits. The concentration of cation, magnesium $(\mathrm{Mg})$ and potassium $(\mathrm{K})$ in the lake water has exceeded the desirable range $(30,10 \mathrm{mg} / \mathrm{L}$, respectively). This may be due to weathering and transported from rocks
\end{abstract}

Javed Mallick

jmallick@kku.edu.sa

King Khalid University Abha, Abha, Asser, Saudi Arabia and particularly from sulphate deposits such as gypsum and anhydride and subsequently ends up in water. The concentration of anion, Sulphate $\left(\mathrm{SO}_{4}\right)$ and chloride are above the desirable limit. The major source of bicarbonate are the carbonate rocks containing calcite $\left(\mathrm{CaCO}_{3}\right)$ and dolomite $\left(\mathrm{CaMg}\left(\mathrm{CO}_{3}\right)_{2}\right)$, Calcium (Ca) and Magnesium $(\mathrm{Mg})$ can also be transported from $\mathrm{Ca}$-silicates and $\mathrm{Mg}$-silicates. The piper trilinear plot suggests the increase of $\mathrm{Ca}$ and $\mathrm{SO}_{4}$ contents is attributed to dissolution of gypsum and anhydrite, which are commonly found in the quaternary formations of watershed (wadi). Ion exchange, dissolution of calcite, semi-arid climate, alkaline condition and weathering are responsible for high concentration of ions exceeding the desirable limit of the study area.

Keywords Physico-geochemical analysis and modelling . Geoinformation technology $\cdot$ Al-Saad Lake

\section{Introduction}

The watershed is all of the land and water areas that drain toward a particular waterway or lake. A lake is a reflection of its watershed. More specifically, a lake reflects the watershed's extent, climate, topography, geology, land use/land cover, soil erodibility, and vegetation. The lakes, their ecosystems and habitats are niches to a wide variety of unique flora and fauna (Moor 1984; Burgis and Mavuti 1987; Chatterjee 1996; Njenga 2004). The lake watershed "system" is a functioning unit with interacting bio-physical, chemical and anthropogenic components.

Lakes water have been utilized as ideal natural laboratories to study a number of hydrogeochemical processes including evaporation, dissolution, mixing, precipitation of minerals and chemical exchange between water, sediment 
and atmosphere (Njenga 2004). The physiognomies of lake-watershed interaction hinge on a number of parameters. That is why each lake and its watershed are a unique system. The usefulness of water for a particular purpose is determined by the water quality. The environmental conditions of any lake system depend upon the nature of that lake and its exposure to various environmental factors. Therefore, surface water quality depends not only on natural processes i.e. precipitation inputs, erosion, and weathering of crustal materials, etc. but also on anthropogenic influences.

The main reasons which resulted in deteriorate conditions of lakes could be categorized into two classes (Ravi et al. 2013) point sources i.e. pollutants entering from fixed sources (for example, nutrients from wastewater, from municipal and domestic effluents; organic, inorganic and toxic pollutants from industries effluents and storm water runoff) and non-point sources (for example, nutrients through fertilizers, toxic pesticides and others chemicals, mainly from agricultural runoff; organic pollution from human settlements spread over areas along the periphery of the lakes).

In Saudi Arabia, surface waters i.e. dams, lakes, and open water reservoirs are considered to be extremely limited resources and are exploited for almost every use (AlOtaibi and Zaki 2012). The land and water resources are under threat from environmental pollution, including from anthropogenic activities by the low levels of hygiene behaviours (Al-Otaibi and Zaki 2012; Punmia and Jain 1998; Akujieze et al. 2003). Environmental health involves all the factors (biological and physical), circumstances and conditions in the environment or human surroundings that can influence health and well-being. In order for it to continue playing its role sustainably, it is important that the quality of water in the reservoir does not deteriorate below acceptable standards, thus its proper monitoring and management on regular basis is necessary.

Hydrogeochemical characteristics and assessment of water quality investigations have been carried out at Abha, located in Saudi Arabia, where Al-Saad Lake represents a rare example of natural endorheic lake. The ecosystem within and around the Al-Saad Lake including catchment area is of great social, cultural, aesthetic, environmental and economic values to Abha.

Integration of spatial data, GIS, GPS technologies provides a useful and valuable tool for monitoring and assessing water quality parameters. Geospatial data can be used to create a permanent geographically located database to provide a baseline for future comparisons. Sajjad-Mustafa Nasir (1999) utilized the GIS, geochemical survey and the simulation of a water quality model of Lake St. Clair, Canada. And it was found that the Geochemical survey indicate that the Clinton River appears to be a significant source of contamination of Lake St. Clair. Remote sensing is a new technique used to map water quality parameters, such as chlorophyll content and suspended matter (Arenz et al. 1996; Dewidar and Khedr 2001; Vincent et al. 2004). This technique can be applied for lakes and reservoirs (Lillesand and Kiefer 1994) and tropical coastal areas (Ruiz-Azuara 1995). In situ monitoring, water quality modelling and spatial distribution of water quality parameters using geographical information system (GIS) can provide an insight about hydro-geochemistry and ecology of water systems (Rewanet 1994; Allewijn et al. 1995). Several projects concerning the integration of data from GIS with in situ measurements and mathematical models have been carried out around the world (Allewijn et al. 1995; Toi et al. 1992; Blaakman et al. 1995; Vos 1995).

This study focuses to assess the levels of certain significant geophysical and chemical water quality parameters and geospatial techniques an integrated scheme for mapping water quality of Al-Saad Lake, Abha. The study's main objective was to assess the hydro-geochemical properties of lake water quality using geospatial and geostatistical approach. Currently, three tools are used for the assessment of lake water quality: (a) water quality monitoring by in situ sampling (b) geospatial analysis and (c) geostatistical modelling. The information derived with each of these tools is of a different nature. Geoinformation technology gives full spatial information of a limited number of parameters.

\section{Study area: geographical setting}

The Lake Al-Saad is situated in Abha, Aseer province of Kingdom of Saudi Arabia. It covers an area of $68,700 \mathrm{~m}^{2}$. The study area lies between the latitude of $18^{\circ} 12^{\prime} 29.355^{\prime \prime} \mathrm{N}, \quad 18^{\circ} 12^{\prime} 51.436^{\prime \prime} \mathrm{N}$ and longitude of $42^{\circ} 29^{\prime} 5.157^{\prime \prime} \mathrm{E}, 42^{\circ} 29^{\prime} 19.795^{\prime \prime} \mathrm{E}$ (Fig. 1). The surface elevation from the mean sea level of Al-Saad is $2282 \mathrm{~m}$. The area and shoreline of the lake is 6.87 ha and $2354 \mathrm{~m}$, respectively, the average depth and maximum depth are 2.42 and $6.00 \mathrm{~m}$, respectively, it plays an important role especially in the local eco-sustainability and social values. The climatic condition in the surrounding study area is semi-arid. The average annual rainfall of $355 \mathrm{~mm}$ with the bulk of the precipitation is occurring between June and October and average minimum and maximum temperatures of 19.3 and $29.70{ }^{\circ} \mathrm{C}$, respectively. The surroundings of Lake Al-Saad embrace one of the richest and the most variable floristic regions of Aseer Mountains, southwest of Saudi Arabia. Jabal Al-Sooda, located about $30 \mathrm{~km}$ in the north western part of the study area, having $2992 \mathrm{~m}$ high, has also a rich flora. The variation in climate and topography in the study area (Aseer Province) has led to the 


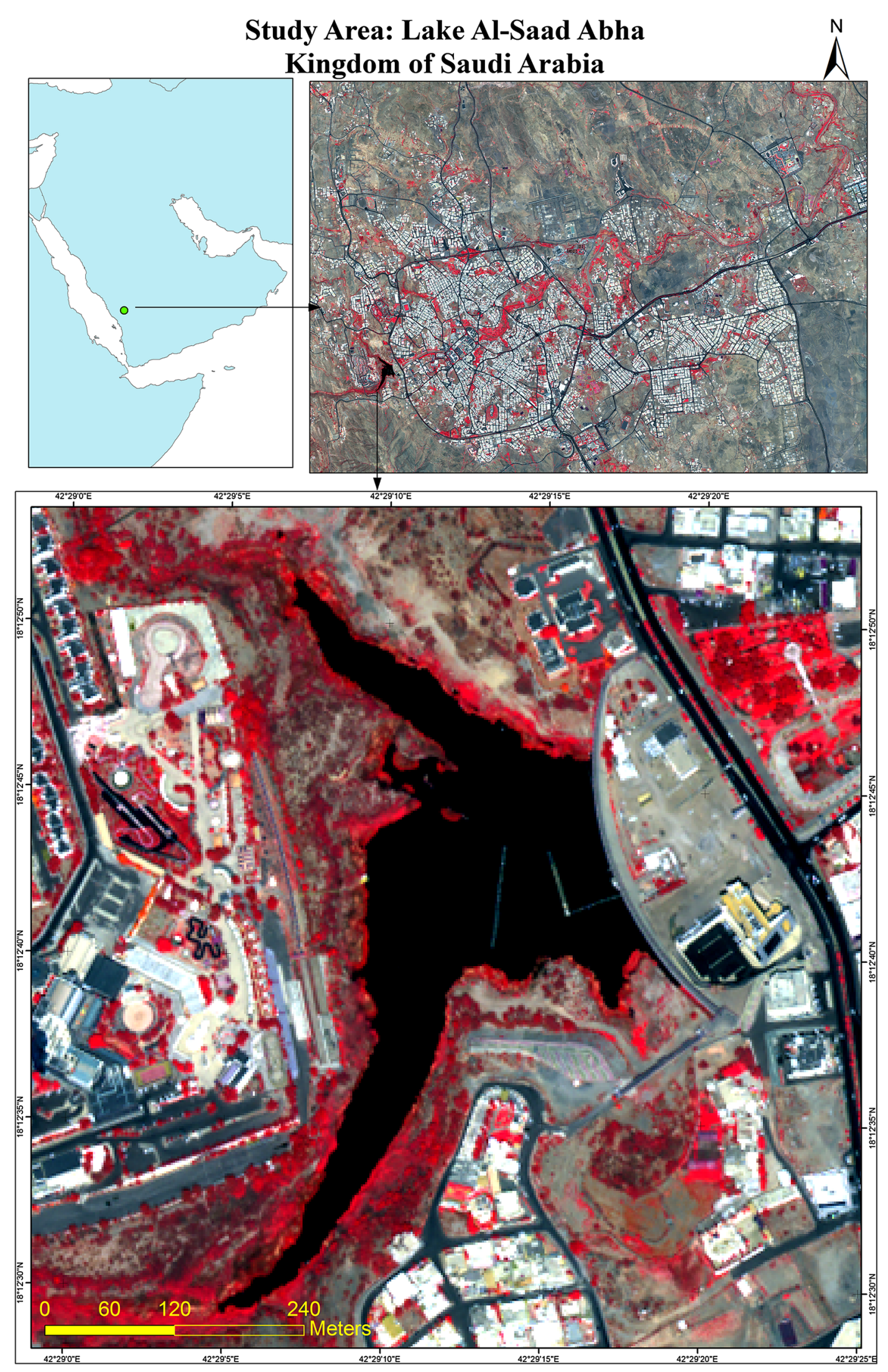

Fig. 1 Study area 
formation of diverse plant community (Abulfatih 1981). Acacia trees are widely distributed to the surrounding of the study area. The land use/land covers surrounds the lake are built-up, vegetation, wastelands, baresoil, exposed rocks and agricultural lands (Mallick et al. 2013).

\section{Geo-physical characteristics of the catchment area of lake Al-Saad}

Geological characteristics of the catchment area of lake AlSaad is underlain predominately by metamorphosed volcanic and sedimentary rocks of the Bahah, and Jiddha group and by plutonic rocks ranging in composition from Gabbro to granite. These geological units at an elevation ranging from 1950 to $2950 \mathrm{~m}$ above mean sea level. Three types of geologic lithology are found surrounding of the study area (Saudi geological survey) (Fig. 2).
- Granite Suite-Biotite Monzogranite-Diorite and Gabbro (dg)

- Jiddah Group-Basalt and Andesite-Pillow lava, flow breccia, tuff, dacite tuff, interbedded subordinate, often carbonaceous conglomeratic graywacke and phyllie (jt)

- Jiddah Group-Bahah group within the Tayyah beltVolcaniclastic graywacke, carbonate rock, shale and siltstone, subordinate chert, slate, and conglomerate, minnor interbedded basalt, andesite, and dacite (bt).

Soil texture is the dominate factor in the soil-water potential content relationship (Saxton et al. 1986) and has an important information that is required for physicochemical properties of lake water. The dominate type of soil class are loam, loamy sand, sandy loam and silty loam surrounding the water catchment area of lake (Fig. 2). Soil erosion continues to be a major constraint to vegetation and agricultural productivity. It also causes sedimentation in the lake and is a major source of nutrient loading into the

\section{Geospatial Properties of the Watershed}
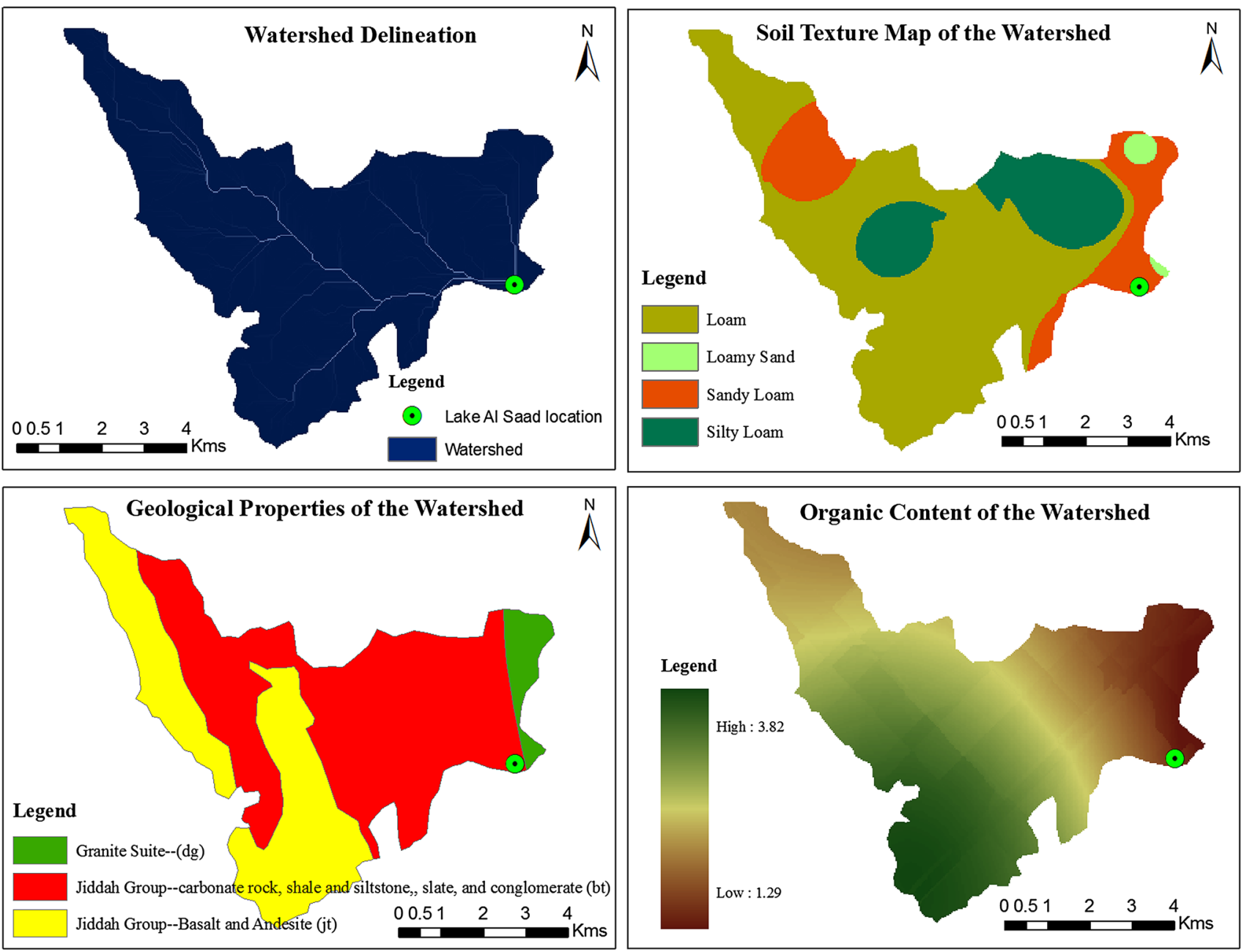

Fig. 2 Geospatial properties of the watershed 
lake. However, there is limited information on the nature, magnitude and impacts of soil erosion. Mallick et al. (2013) has attempted to assess the soil erosion intensity (based 'RUSLE' model integrated with GIS method) to conserve soil and vegetation and rehabilitate vegetation for semi-arid mountainous watershed of Aseer region of Saudi Arabia.

Organic matter content is an important control on erosion because of its effect on aggregate stability and water absorption (Mallick et al. 2015). Figure 2 shows the low organic content in the catchment area, therefore, the concentrations of the ions in the lake water are low.

\section{Materials and methods used}

\section{Field survey and water sample analysis}

Water sample were collected from various spatial locations in the Lake Al-Saad. A total of 46 water samples were collected on 15th October, 2012 in polypropylene bottles immersed 20-30 cm below the water surface. At each site, field measurements were carried out including the geographic location using a differential global positioning system (DGPS Leica GPS1200); The water quality parameters such as dissolved oxygen (DO), $\mathrm{pH}$, total dissolved solid (TDS) and electrical conductivity (EC) were measured onsite using respective portable electrodes. The samples were stored in an icebox, carried to the laboratory and kept at $4{ }^{\circ} \mathrm{C}$ for further chemical analysis. The major cations $\left(\mathrm{Na}^{+}, \mathrm{K}^{+}, \mathrm{Mg}^{2+}, \mathrm{Ca}^{2+}\right)$ were analyzed using an atomic absorption spectrometer (Thermo Fisher Scientific $\mathrm{M}$ series) and the major anions $\left(\mathrm{SO}_{4}{ }^{2-}, \mathrm{NO}_{3}{ }^{-}, \mathrm{F}^{-}, \mathrm{Cl}^{-}\right)$ were analyzed using ion chromatograph (Dionex). Bicarbonate $\left(\mathrm{HCO}_{3}{ }^{-}\right)$was determined by titration method using standard procedures as described in AHPA manual (APHA 2005). The analytical precision of the ions analyzed was determined by calculating the normalized ionic charge balance error, which varied within $\pm 5 \%$. ArcGIS 10.1 software was used in this study to create the geodatabase and to perform geostatistical analysis.

\section{Geostatistical and geospatial analysis of water sample}

Statistical parameters (mean, median, minimum, maximum, standard derivation, Skewness, kurtosis and the coefficient of variation) were computed for each water quality parameter by the software package SPSS. The statistical data analysis included a Pearson correlation analysis. Prior to the geostatistical data analysis, the data were tested for normality using $\mathrm{K}-\mathrm{S}$ (Kolmogorov-Smirnov) test for goodness of fit (Marsaglia et al. 2003).
Geostatistical analysis comprise a group of spatial statistical techniques that evaluate the autocorrelation commonly observed in geospatial data, where the data values from locations close to each other are more symmetry than the data values from locations far apart.

Spatial interpolation technique is commonly used to generate continuous information when the point data information is available at several sampling locations (water quality parameters).

Three commonly used interpolation methods to model spatially distribution from point data are Inverse Distance Weighting (IDW), spline and ordinary kriging. The IDW is simple and intuitive deterministic interpolation method based on principle that sample values closer to the prediction location have more influence on prediction value than sample values farther apart. Whereas, the ordinary kriging $(\mathrm{OK})$ is an improvement over inverse distance weighting (IDW) because prediction estimates tend to be less bias and because predictions are accompanied by prediction standard errors (quantification of the uncertainty in the predicted value).

In ordinary kriging $(\mathrm{OK})$ model, weighs the surrounding known value to derive estimations for an unmeasured location. Though, the weights are based not only on the distance between the known values and unknown values but also on the overall geostatistical relationships among the known values. OK method is based on the creation of a semi-variogram and from the information contained in the best fitted model of the semi-variogram the interpolation values are determined. The semi-variogram is a plot between the distance of ordered data and their value of semivariance, this plot explains the spatial relation between the water analyzed values, and is given by the following Eq. (1)

$\gamma(h)=\frac{1}{2} N_{(h)} \sum\left[Z_{i}-Z_{i+h}\right]^{2}$.

The most related samples have lower values of semivariance $(\gamma(h)) . N_{(h)}$ is the number of water quality parameter values that can be grouped using vector $h ; Z_{i}$ is the value of the water parameters; $Z_{i+h}$ represents the value of another sample located at a distance " $h$ " from the initial sample $Z_{i}$. The semi-variogram is a point graphic with points plotted at specific distance interval, since there is the need to know semivariance value at distances not defined in the plot, a model was fitted using the lowest possible root square error (RSE). The "best fit" model provides two important parameters nugget and sill to determine whether the samples are spatially correlated or not. If the ratio between nugget and sill is low, i.e. $<0.25$ then the samples are spatially correlated, contrary if the ratio is high, i.e. $>0.75$ then the samples have a very low spatial correlation (Castrignano et al. 2007). This parameter indicates the 
spatial structure of the phenomenon and samples with a high spatially relationship will show better interpolation results. Prior to creating continuous surface, the distribution of the different water quality properties is analyzed to better understand the trends, which influences directional and obvious errors. Transformation and trend removal was performed when necessary. Kriging crossvalidation was used to estimate that of the semi-variogram models could give the most accurate predictions at unknown locations. The closer the mean error was to zero, the closer the root-mean-square standardized error was to 1 , signified that the prediction values were close to measured values (Castrignano et al. 2007). Where models presented similar values for mean error and root-meansquare error, the lowest values of root-mean-square error and average standard error were taken into consideration.

\section{Results and discussion}

\section{Geostatistical analysis of lake water quality parameters}

Lake water samples were taken from 46 locations in the study area. The general guidelines for selecting the water sample are as follows: Consider the study objectives, data type and quality of data needed, equipment or instrument needs, and sampling methods. Consider physical characteristics of the area, such as size and shape, surrounding land use/land cover, runoff characteristics, point and nonpoint sources of pollution, water depth, and sediment transport characteristics. Avoid areas near structures such as docks, boat ramps, and fuel docks, unless these structures are part of the study.

Herein, the data checked by histogram tool and normal QQPlots of ArcGIS software, to see if it shows a normal distribution pattern. Normal QQPlots give an indication of univariate normality. If the data is asymmetric (i.e., far from normal), the points will deviate from the line. Histogram and normal QQPlots analysis were found that only $\mathrm{pH}$ and DO parameters showed normal distribution. It was determined that electrical conductivity, chloride, Sulphate, nitrate, sodium, potassium, magnesium and calcium concentrations do not show normal distributions. For those water quality parameters, a log transformation has been applied to make the distribution closer to normal. For each water quality parameters, an analysis trend was created and it was determined that there is no global trend for all parameters. In this study, the semivariogram models (circular, spherical, tetraspherical, pentaspherical, exponential, rational quadratic, Gaussian, Hole effects, K-Bessel, J-Bessel, and stable) were tested for each parameter dataset. Prediction performances were assessed by cross validation, which examines the accuracy of the generated surfaces.

The cross-validation results of the value of estimated mean error (ME) were very low, i.e. close to zero, which shows that an oblique can be estimated by kriging interpolation methods. In addition, the low values of the root mean square of error (RMSE) inferred that the estimated had an acceptable accuracy range. Hence, the results of the control semi-variogram show the suitability of estimated by Kriging. Table 1 shows summarily the indicators which helped to choose the most appropriate model of semi-variogram for the creation of interpolated or prediction maps. Nugget was low in most of the examine water samples studied that indicate the strong spatial dependence, but some large effects, in the case of $\mathrm{SO}_{4}$, and $\mathrm{Cl}$ ions, of the semi-variograms indicated a high variance at short distance. The nugget/sill ratio shows highly spatially dependence for most parameters studies, i.e. EC, TDS, $\mathrm{pH}, \mathrm{DO}$, $\mathrm{Cl}, \mathrm{NO}_{3}, \mathrm{Na}, \mathrm{Ca}$ and depth but moderate-weak for $\mathrm{SO}_{4}$ and weak for $\mathrm{K}$ and $\mathrm{F}$.

The lake water quality prediction maps showing the concentration distribution generated from the surface map developed from the cross validation process discussed above. Figure 4 shows the spatial distribution of $\mathrm{pH}, \mathrm{DO}$, EC, TDS, $\mathrm{Mg}^{2+}, \mathrm{Ca}^{2+}, \mathrm{Na}^{+}, \mathrm{K}^{+}, \mathrm{SO}_{4}{ }^{2-}, \mathrm{Cl}^{-}, \mathrm{HCO}_{3}$, $\mathrm{NO}_{3}{ }^{-}$and $\mathrm{F}^{-}$concentration of the study area. The result of OK interpolation showed that higher Sulphate, nitrate, electrical conductivity, $\mathrm{pH}$ and hardness concentrations clearly situated in the north eastern of the study area.

\section{Statistical analysis lake water quality parameters}

The statistical parameters of various physico-chemical parameters of water that were analyzed are given in Table 2. The chemical analysis results shows the abundance of the major cations in the order $\mathrm{Mg}>\mathrm{Ca}>$ $\mathrm{Na}>\mathrm{K}$, whereas the abundance of anions are in the order $\mathrm{SO}_{4}>\mathrm{Cl}>\mathrm{HCO}_{3}>\mathrm{NO}_{3}>\mathrm{F}$. Water hardness is caused primarily by the presence of cations such as $\mathrm{Mg}, \mathrm{Ca}, \mathrm{Na}$, and anions such as bicarbonate, $\mathrm{Cl}$, and $\mathrm{SO}_{4}$ in water.

A Pearson correlation matrix has been created for the examined water quality parameters to decipher the relationship among the various ions (Table 3). All the cations, $\mathrm{Na}, \mathrm{K}$, and $\mathrm{Ca}$ showed a very good positive correlation with $\mathrm{pH}$ of $(R)$ value $0.734,0.735$ and 0.620 , respectively. Whereas, EC and TDS showed a good positive correlation with $\mathrm{pH}, R$ value of 0.548 and 0.528 , respectively, a correlation of EC with TDS is evaluated and it is found a very good positive correlation of $R$ value 0.966 . Thereafter, a correlation of EC and TDS with examined water samples parameters is also evaluated. All the cations, $\mathrm{Na}, \mathrm{K}$, and $\mathrm{Ca}$ showed a very good positive correlation with EC and TDS of $(R)$ value $0.636,0.611$ and $0.525 ; 0.624,0.570$ and 
Table 1 Result of the semi-variogram function modelling used to create the prediction maps of the water quality

\begin{tabular}{|c|c|c|c|c|c|c|c|c|c|c|c|c|c|c|c|}
\hline $\begin{array}{l}\text { Water } \\
\text { property }\end{array}$ & TDS & $\mathrm{pH}$ & $\mathrm{EC}$ & DO & $\mathrm{Na}$ & $\mathrm{K}$ & $\mathrm{Ca}$ & $\mathrm{Mg}$ & $\mathrm{Fe}$ & $\mathrm{F}$ & $\mathrm{Cl}$ & $\mathrm{NO}_{3}$ & $\mathrm{SO}_{4}$ & $\mathrm{HCO}_{3}$ & Depth \\
\hline Model & GS & Sph. & GS & GS & Sph. & Sph. & Exp. & Sph. & Sph. & Sph. & RQ & GS & Sph. & $\mathrm{CR}$ & Exp. \\
\hline Nugget & 2.26 & 0.00 & 3.94 & 0.00 & 0.19 & 0.48 & 5.81 & $29,279.00$ & 0.00 & 0.01 & 1225.30 & 0.01 & 5211.10 & 401.17 & 0.12 \\
\hline Sill & 2263.70 & 0.01 & 3935.90 & 0.32 & 6.23 & 0.33 & 38.44 & $32,010.00$ & 0.00 & 0.01 & 8216.90 & 7.08 & $10,260.00$ & 800.23 & 1.87 \\
\hline Range & 40.95 & 617.06 & 41.93 & 44.30 & 635.18 & 116.37 & 635.18 & 101.90 & 45.89 & 649.59 & 77.83 & 27.82 & 31.26 & 96.76 & 146.23 \\
\hline ME & 0.65 & 0.00 & -0.15 & 0.03 & 0.02 & 0.02 & 0.05 & -1.71 & 0.00 & 0.00 & -0.22 & 0.13 & 1.34 & -0.74 & 0.03 \\
\hline RMSE & 41.81 & 0.03 & 56.26 & 0.51 & 1.11 & 0.81 & 4.30 & 242.80 & 0.01 & 0.12 & 99.30 & 2.98 & 124.10 & 35.47 & 0.90 \\
\hline ASE & 45.95 & 0.03 & 60.35 & 0.55 & 0.92 & 0.87 & 3.80 & 238.80 & 0.01 & 0.12 & 96.95 & 2.84 & 124.20 & 31.26 & 1.17 \\
\hline MS & 0.02 & 0.01 & 0.00 & 0.04 & 0.01 & 0.02 & 0.01 & -0.01 & -0.01 & 0.00 & 0.00 & 0.05 & 0.01 & -0.02 & 0.03 \\
\hline RMSSE & 0.92 & 0.91 & 0.95 & 0.92 & 1.22 & 0.95 & 1.14 & 1.02 & 1.00 & 1.00 & 1.02 & 1.04 & 1.00 & 1.12 & 0.03 \\
\hline $\begin{array}{l}\text { Nugget/ } \\
\text { sill }\end{array}$ & 0.00 & 0.03 & 0.00 & 0.00 & 0.10 & 1.47 & 0.15 & 0.91 & 0.95 & 0.90 & 0.15 & 0.00 & 0.51 & 0.50 & 0.07 \\
\hline
\end{tabular}

Exp exponential, Sph spherical, $R Q$ rational quadratic, $G S$ Gaussian, $C R$ circular

Table 2 Summary of physical and chemical parameters of lake Al-Saad

\begin{tabular}{lllllllllllllll}
\hline Sample no. & $\mathrm{Na}$ & $\mathrm{K}$ & $\mathrm{Ca}$ & $\mathrm{Mg}$ & $\mathrm{Cl}$ & $\mathrm{NO}_{3}$ & $\mathrm{SO}_{4}$ & $\mathrm{~F}$ & $\mathrm{HCO}_{3}$ & $\mathrm{EC}$ & $\mathrm{TDS}$ & $\mathrm{pH}$ & $\mathrm{DO}$ & $\mathrm{Depth}$ \\
\hline Minimum & 77.10 & 9.30 & 148.90 & 46.45 & 558.60 & 1.01 & 1339.05 & 0.08 & 23.65 & 3366.00 & 2010.00 & 7.76 & 4.40 & 0.42 \\
Maximum & 85.30 & 11.60 & 173.50 & 722.98 & 916.23 & 8.96 & 1887.56 & 0.58 & 190.85 & 3710.00 & 2260.00 & 8.12 & 6.71 & 6.00 \\
Mean & 83.26 & 11.27 & 167.16 & 492.81 & 677.21 & 3.55 & 1545.06 & 0.33 & 78.34 & 3637.80 & 2198.64 & 8.06 & 5.40 & 2.36 \\
Std. dev & 1.49 & 0.49 & 4.69 & 204.68 & 92.88 & 2.09 & 128.33 & 0.13 & 29.90 & 62.45 & 46.98 & 0.07 & 0.56 & 1.37 \\
Skewness & -2.51 & -3.24 & -1.56 & -0.97 & 1.10 & 1.07 & 0.97 & 0.05 & 1.30 & -3.37 & -2.71 & -3.41 & 0.26 & 0.61 \\
Kurtosis & 8.30 & 11.21 & 4.54 & -0.41 & -0.09 & 0.40 & 0.60 & -0.79 & 3.63 & 12.35 & 8.20 & 12.90 & -0.28 & -0.437 \\
SASO standard & 200 & 10 & 200 & 150 & 250 & $<45$ & 400 & $0.6-1$ & $\mathrm{NS}$ & $50-1500$ & 1500 & $6.5-9.0$ & 10 & NA \\
GCC standard & 200 & 10 & 200 & 150 & 250 & $<45$ & 400 & $0.6-1$ & $\mathrm{NS}$ & $50-1500$ & 1000 & $6.5-8.5$ & 10 & NA \\
WHO guidelines & $\mathrm{NS}$ & $\mathrm{NS}$ & $\mathrm{NS}$ & $\mathrm{NS}$ & 250 & 50 & $\mathrm{NS}$ & 1.5 & $\mathrm{NS}$ & $\mathrm{NS}$ & 1000 & $<8.0$ & NS & NA \\
\hline
\end{tabular}

Concentrations are in $\mathrm{mg} / \mathrm{L}$, except for EC $(\mu \mathrm{S} / \mathrm{cm})$ and $\mathrm{pH}$

$N A$ not available, $N S$ not specified

0.531, respectively. Whereas, EC and TDS showed a good positive correlation with $\mathrm{pH}, R$ value of 0.548 and 0.528 , respectively.

The cations, $\mathrm{Na}, \mathrm{K}$, showed a very good positive correlation with $\mathrm{Ca} R$ value $0.607,0.517$, respectively. EC, TDS and $\mathrm{pH}$ showed a good positive correlation with $\mathrm{Ca}$, with $R$ value of $0.525,0.531$ and 0.620 , respectively, the linear correlation coefficient of $\mathrm{Ca}$ with examined water samples (Table 4), it was found that the variables between calcium and $\mathrm{Na} / \mathrm{K}$ has a very high negative correlation of $R^{2}$ value $=0.85$ this is due to the geological formation of surrounding area such as shale, siltstone and carbonaceous rocks and indicating the dominance of ion-exchange process. The cations, $\mathrm{Mg}$, showed a very high negative correlation with $\mathrm{Cl}$ and $\mathrm{SO}_{4}$ of $R$ value -0.837 and -0.648 , respectively, the linear correlation coefficient of $\mathrm{Mg}$ with examined water samples, it was found that the variables between chloride has a very high negative correlation of $R^{2}$ value $=-0.70$ and with sulphate having moderate negative correlation of $R^{2}=-0.42$. The Pearson correlation of sodium (Na) with examined water sample parameters is evaluated (Table 4) and found that there is very good positive correlation all the cations, $\mathrm{K}$, and $\mathrm{Ca}$ of $R$ value $0.763,0.607$, respectively, moreover, there is also good correlation with EC, TDS and $\mathrm{pH}$ with $\mathrm{Na}$ showed very good positive correlation of $R$ value $0.636,0.624$ and 0.734 , respectively, there is negative correlationship with DO $(-0.212)$ although it is not significant. By examine of the linear correlation coefficient among the examined water parameters (Table 4), it was observed that there was a good correlation between the variable of $\mathrm{Na}$ with $\mathrm{K}$ of $R^{2}=0.58$ and $\mathrm{Na}$ with $\mathrm{pH}$ of $R^{2}=0.54$.

The concentration of $\mathrm{Na}$ is found to vary between 82.6 and $84.70 \mathrm{mg} / \mathrm{L}$. The Skewness results indicated that DO, $\mathrm{F}, \mathrm{Mg}, \mathrm{SO}_{4}, \mathrm{Na} / \mathrm{Ca}$, depth properties were normally distributed (Skewness -1 and 1), whereas TDS, EC, pH and 
Table 3 Pearson correlation matrix of physico-chemical parameters of examined water samples

\begin{tabular}{|c|c|c|c|c|c|c|c|c|c|c|c|c|c|c|c|}
\hline & $\mathrm{Na}$ & $\mathrm{K}$ & $\mathrm{Ca}$ & $\mathrm{Mg}$ & $\mathrm{Fe}$ & $\mathrm{Cl}$ & $\mathrm{NO}_{3}$ & $\mathrm{SO}_{4}$ & $\mathrm{~F}$ & $\mathrm{HCO}_{3}$ & $\mathrm{Na} / \mathrm{Ca}$ & $\mathrm{EC}$ & TDS & $\mathrm{PH}$ & DO \\
\hline $\mathrm{Na}$ & 1.000 & & & & & & & & & & & & & & \\
\hline $\mathrm{K}$ & 0.763 & 1.000 & & & & & & & & & & & & & \\
\hline $\mathrm{Ca}$ & 0.607 & 0.517 & 1.000 & & & & & & & & & & & & \\
\hline $\mathrm{Mg}$ & -0.158 & -0.236 & -0.123 & 1.000 & & & & & & & & & & & \\
\hline $\mathrm{Fe}$ & 0.357 & 0.194 & 0.342 & -0.189 & 1.000 & & & & & & & & & & \\
\hline $\mathrm{Cl}$ & 0.256 & 0.279 & 0.177 & -0.837 & 0.156 & 1.000 & & & & & & & & & \\
\hline $\mathrm{NO}_{3}$ & 0.195 & 0.263 & 0.269 & -0.205 & 0.137 & 0.264 & 1.000 & & & & & & & & \\
\hline $\mathrm{SO}_{4}$ & 0.303 & 0.262 & 0.091 & -0.648 & 0.122 & 0.852 & 0.131 & 1.000 & & & & & & & \\
\hline$F$ & 0.284 & 0.110 & 0.312 & 0.110 & 0.165 & -0.059 & 0.283 & -0.026 & 1.000 & & & & & & \\
\hline $\mathrm{HCO}_{3}$ & 0.160 & 0.138 & 0.204 & 0.198 & 0.030 & 0.103 & 0.279 & -0.072 & 0.032 & 1.000 & & & & & \\
\hline $\mathrm{Na} / \mathrm{Ca}$ & -0.037 & -0.159 & -0.928 & 0.076 & -0.098 & -0.070 & -0.252 & 0.077 & -0.169 & -0.165 & 1.000 & & & & \\
\hline $\mathrm{EC}$ & 0.636 & 0.611 & 0.525 & 0.042 & 0.262 & 0.167 & 0.130 & 0.189 & 0.363 & 0.022 & -0.077 & 1.000 & & & \\
\hline TDS & 0.624 & 0.570 & 0.531 & 0.078 & 0.244 & 0.123 & 0.078 & 0.153 & 0.351 & -0.032 & -0.105 & 0.966 & 1.000 & & \\
\hline $\mathrm{pH}$ & 0.734 & 0.735 & 0.620 & -0.194 & 0.380 & 0.241 & 0.219 & 0.250 & 0.134 & 0.107 & -0.135 & 0.548 & 0.528 & 1.000 & \\
\hline DO & -0.212 & -0.106 & -0.052 & 0.387 & 0.021 & -0.221 & -0.463 & -0.065 & 0.077 & -0.322 & 0.024 & -0.017 & 0.033 & -0.207 & 1.000 \\
\hline
\end{tabular}

The bold values represent correlation is significant at the level 0.01 (2-tailed)

Table 4 Linear correlation coefficient of examined water quality parameters

\begin{tabular}{llll}
\hline Variable & Relationship & $R^{2}$ & Linear correlation model \\
\hline Sodium with potassium & Positive & 0.5818 & $y=0.2485 x-9.4209$ \\
Sodium with calcium & Positive & 0.3690 & $y=2.168 x-13.713$ \\
Sodium with $\mathrm{pH}$ & Positive & 0.5389 & $y=0.0375 x+4.9353$ \\
Potassium with $\mathrm{pH}$ & Positive & 0.5399 & $y=0.1276 x+6.6209$ \\
Calcium with $\mathrm{Na} / \mathrm{K}$ & Negative & 0.8449 & $y=-0.0029 x+0.9905$ \\
Potassium with calcium & Positive & 0.2674 & $y=6.2681 x+96.13$ \\
Calcium with pH & Positive & 0.3848 & $y=0.0087 x+6.6008$ \\
Sodium with TDS & Positive & 0.3894 & $y=22.675 x+307.93$ \\
Chloride with sulphate & Positive & 0.7264 & $y=1.1775 x+747.64$ \\
Magnesium with chloride & Negative & 0.7008 & $y=-0.3471 x+836.86$ \\
Magnesium with sulphate & Negative & 0.4197 & $y=-0.3878 x+1724.1$ \\
Nitrate with DO & Negative & 0.2141 & $y=-0.1208 x+5.855$ \\
EC with TDS & Positive & 0.9329 & $y=0.7267 x-444.88$ \\
EC with pH & Positive & 0.3004 & $y=0.0006 x+5.9511$ \\
\hline
\end{tabular}

other microelement $\mathrm{Na}, \mathrm{K}, \mathrm{Ca}, \mathrm{Cl}, \mathrm{HCO}_{3}, \mathrm{NO}_{3}$ ions was not normally distributed (Skewness more than +1 or less than -1) (Fig. 3).

\section{Hydro-geochemistry of lake water}

The $\mathrm{pH}$ value for the lake water ranges from 7.7 to 8.1 (Fig. 4). A desirable range of $\mathrm{pH}$ for aquatic life is 6.5-9.0 (Klein 1973). pH above or below this threshold value might interfere with reproduction, respiration and other biological functions of aquatic life. Although the tolerance of individual species varies, $\mathrm{pH}$ values between 6.5 and 8.5 usually indicate good water quality and this range is typical of most major drainage basins of the world (Chin 2000). The ability of rocks and soils in any given drainage basin to buffer the acidity of rainwater is related to the residence time of water in the soil as well as the levels of calcium carbonate, bicarbonate, and silicate minerals (Friedl et al. 2004). Watersheds with soil rich in calcium carbonate will provide buffering to lakes, which otherwise with low buffering capacity would be susceptible to acid deposition or acid runoff. DO of the lake water was in the range of 

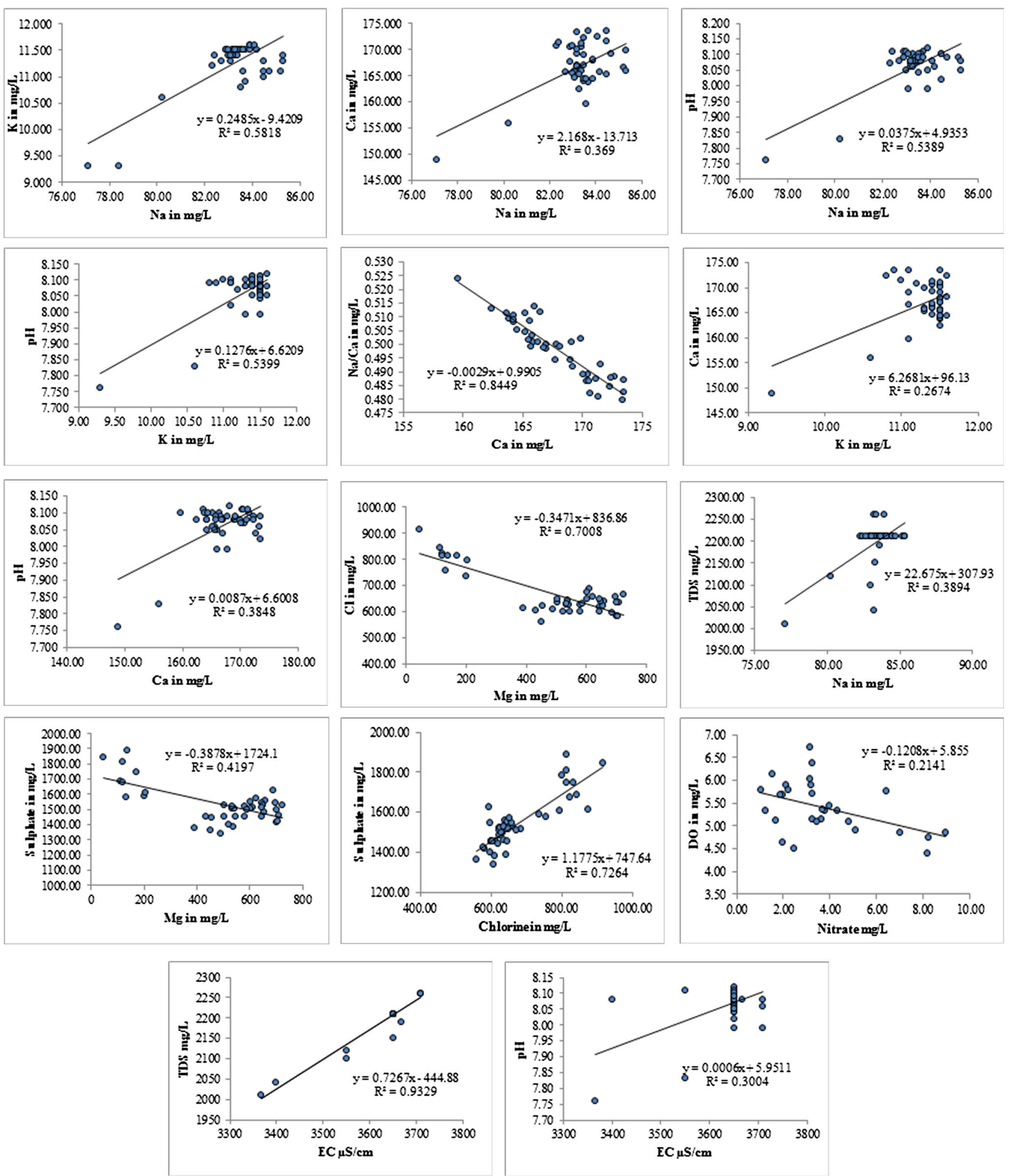

Fig. 3 Linear correlation coefficient of water quality parameters of Lake Al-Saad

4.38-6.73 mg/L with the mean of $5.38 \mathrm{mg} / \mathrm{L}$ (Fig. 4). The available data indicated that Lake Al-Saad water is slight lower than the permissible limit of Saudi standards for lake water $(10 \mathrm{mg} / \mathrm{L})$. The $\mathrm{DO}$ in an aquatic ecosystem is responsible for various biochemical changes and subsequently its effect on metabolic activities of organisms within the lake ecosystem. In a nutrient-rich water body, the DO is quite high in the surface water due to increased 
Spatial distribution of Physico-Chemical Properties of Lake-AlSaad
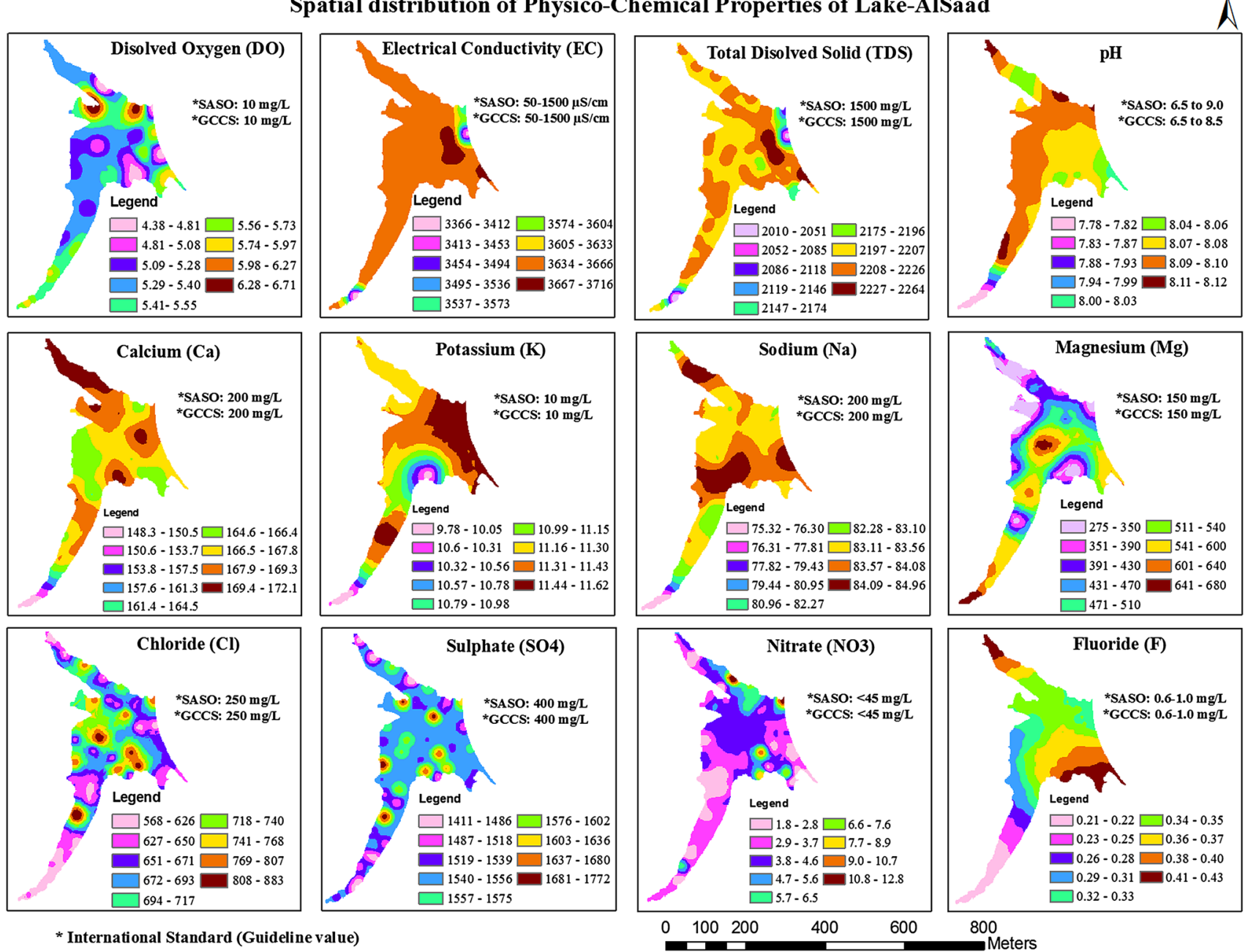

Fig. 4 Spatial distribution of physico-chemical properties of Lake Al-Saad

photosynthesis by the large quantities of algae. However, DO tends to decrease in deeper waters because photosynthesis is reduced due to poor light penetration and due to the fact that dead algae falls towards the bottom using up the oxygen as it decompose. In the study area it is found that the shallow water has high DO concentration, whereas deeper shows significantly lower down. DO is the single most important gas for most aquatic organisms. When the aquatic organisms exposure to less than $2.0 \mathrm{mg} / \mathrm{L}$ free oxygen for few days it may kill most of biota in the aquatic system (Goel and Sharma 1996), while values of $5.0-6.0 \mathrm{mg} / \mathrm{L}$ are usually for most of fish population. The DO trend in Al-Saad Lake is not very encouraging as majority of the lake area is under DO stress or marginally above it. So a proper management strategies need to be formulated to protect flora and fauna of the lake. Conductivity measurements serve as a useful indicator of the degree of mineralization in the water sample. All the samples with EC have exceeded the limit and that ranges from 3366 to $3710 \mu \mathrm{S} / \mathrm{cm}$ with the mean value of 3637.79 $\mu \mathrm{S} / \mathrm{cm}$. EC of most natural water generally ranges about $50-1500 \mu \mathrm{S} / \mathrm{cm}$. In general, with increase of EC, the corrosive nature of the water increases. In the Fig. 4 shows the spatial distribution of EC and TDS, it inferred that the EC and TDS concentration is the highest at the eastern part of the lake whereas concentration drops down towards the southern side.

\section{Hydro-geochemistry of major cations $\left(\mathrm{Na}^{+}, \mathrm{K}^{+}\right.$, $\mathrm{Ca}^{2+}$ and $\mathrm{Mg}^{2+}$ )}

Calcium may dissolve readily from rocks or be transported from soils and other sources municipal discharges. Typically, $\mathrm{Ca}$ concentration in natural freshwater falls below $10 \mathrm{mg} / \mathrm{L}$, although water in the proximity of carbonate rocks and limestone may contain calcium ranging $30-100 \mathrm{mg} / \mathrm{L}$. Figure 4 shows the spatial distribution of $\mathrm{Ca}$, and it is inferred that the concentration of $\mathrm{Ca}$ ranges 
148.31-172.07 mg/L with the mean of $167.23 \mathrm{mg} / \mathrm{L}$. The concentration of $\mathrm{Ca}$ in the lake water is within the desirable range as per the GCS (1993/149) and SAS (1993/701) $(200 \mathrm{mg} / \mathrm{L})$ but it is exceeded as per the EEC (European Economic) $(100 \mathrm{mg} / \mathrm{L})$, this is due to it may dissolve readily from rocks (water in the proximity of carbonate rocks and limestone) or be transported from soils as the geological characteristics (Mallick et al. 2013) of the surrounding study area. Magnesium is often associated with calcium in all natural waters. Magnesium poses no major concern with regards to public health, and limits of concentration set for the water are based mainly on palatability, corrosion and incrustation criteria. Magnesium is essential for chlorophyll growth and acts as a limiting factor for the growth of phytoplankton (Dagaonkar and Saksena 1992). Therefore, reduction in magnesium content may be reduces the number of phytoplankton's population. Although $\mathrm{Mg}$ is an essential nutrient in aquatic systems, it is normally not the limiting nutrient in lakes. Normally, $\mathrm{N}$, $\mathrm{P}$, and perhaps $\mathrm{Si}$ are the limiting nutrients in a lake, and therefore these are normally the nutrients that will limit phytoplankton growth.

The spatial distribution of $\mathrm{Mg}$ (Fig. 4), and it is inferred that the concentration of $\mathrm{Mg}$ ranges $275.19-679.77 \mathrm{mg} / \mathrm{L}$ with the mean of $478.96 \mathrm{mg} / \mathrm{L}$. The concentration of $\mathrm{Mg}$ in the lake water is exceeded the desirable range $(150 \mathrm{mg} / \mathrm{L}$, as per the GCS (1993/149) and SAS (1993/701) limit). This is due to it may washed from rocks and subsequently ends up in water. Water in contact with igneous rocks will dissolve sodium from its natural sources. Sodium may also enter natural waters through municipal waste discharges and run off from diffuse sources. In general, highly mineralized waters usually contain high concentration of sodium. The concentration of sodium in the lake water is within the desirable range $200 \mathrm{mg} / \mathrm{L}$ as per the Gulf Cooperation Council Standards (GCCS) (1993/149). It is inferred from the map that the high concentration is found towards the northwest and south central part of the lake whereas the lowest concentration is found in south part of the lake area. Despite its abundance in nature, potassium $(\mathrm{K})$ is found in relatively small concentrations in most natural waters mainly because of its being reconstituted into insoluble secondary minerals formed in the process of weathering. Its concentration is natural surface water is generally below the $10 \mathrm{mg} / \mathrm{L}$ level (Bureau of Indian Standards (BIS) 2003). Figure 4 showed the spatial distribution of potassium $(\mathrm{K})$ in the lake water, and it is inferred from the map that the high concentration of $\mathrm{K}$ is found towards the eastern part of lake area, whereas the lowest towards the south and central southern part of lake area. The concentration ranges from 9.78 to $11.62 \mathrm{mg} / \mathrm{L}$ with the mean of $11.22 \mathrm{mg} / \mathrm{L}$, which exceeded the desirable limit as per the Bureau of Indian Standards (BIS) (2003). This is may be its being reconstituted into insoluble secondary minerals formed in the process of weathering, as the study area having high weathering rate (Mallick et al. 2013).

\section{Hydro-geochemistry of major anions $\left(\mathrm{Cl}^{-}, \mathrm{SO}_{4}{ }^{2-}\right.$, $\mathrm{NO}_{3}^{-}, \mathrm{F}^{-}, \mathrm{HCO}_{3}$ )}

Chloride is an anion found in variable amounts in natural waters and waste water. The chloride content normally increases as the mineral content increases. Figure 4 shows the spatial distribution of chloride content in $\mathrm{mg} / \mathrm{L}$. In the map it is inferred that in the central part of lake area, whereas lower concentration is found towards the southern part of lake area. The distribution of chloride content values, ranges from 567 to $883 \mathrm{mg} / \mathrm{L}$ with the mean value of $689 \mathrm{mg} / \mathrm{L}$. the concentration is exceeded the desirable limit [250 mg/L, as per the GCCS (1993/149) and SAS (1993/ 701) limit] due to weathering, derives from sedimentary rocks and transported soil. It also may be due to domestic waste discharge and effluents that may be coming out through the Wadies channel. The salts of sodium, potassium and calcium contribute chloride in water. The large contents of chloride in freshwater is an indicator of pollution (Venkatasubramani and Meenambal 2007). The high chloride concentration levels in water contribute to deteriorate on the domestic plumbing, water heaters and municipal water words equipment. Sulphate may enter natural waters through weathering of sulphide-bearing or by direct dissolution of evaporation deposits. Another significant source to water systems is airborne pollutants containing oxides of sulphur, which convert to sulphuric acid in precipitation. Sulphate is of great importance in public water supplies because of its cathartic effect upon humans when it is present in excessive amounts. Diarrhoea can be induced at sulphate levels greater than $500 \mathrm{mg} / \mathrm{L}$ but typically near $750 \mathrm{mg} / \mathrm{L}$ (Bureau of Indian Standards (BIS) 2003). Figure 4 shows the spatial distribution of Sulphate concentration, it is showed that central part of lake area, ranges from 1411 to $1772 \mathrm{mg} / \mathrm{L}$ with the mean value of $1551 \mathrm{mg} / \mathrm{L}$. The concentration highly exceeded the desirable limit (400 mg/ L, as per the GCCS (1993/149) and SAS (1993/701) limit). This may be weathering and transported from sedimentary rocks and particularly from sulphate deposits such as gypsum and anhydride (Singh et al. 2012).

Nitrate anion concentration depends on the activity of nitrifying bacteria which in turn get influenced by presence of dissolved oxygen. In excessive amounts, it contributes to an illness known as methemoglobinemia in infants. A limit of $10 \mathrm{mg} / \mathrm{L}$ has been imposed on drinking water to prevent this disorder. The spatial distribution of nitrate and it is inferred that the mean value is found $3.89 \mathrm{mg} / \mathrm{L}$. The highest concentration ranges $7-12.8 \mathrm{mg} / \mathrm{L}$ are located the small patches at north central and north eastern part of lake, 
this may due high algae (phytoplankton) production, decaying macrophyte, fertilizers from the agricultural land and decomposition of aquatic plants owing to the evaporation of lake water with subsequent increase in nitrate value. High nitrate normally leads to high phytoplankton productivity as it fertilizes the phytoplankton. Fluoride levels in lakes are likely regulated by the calcium-carbonate-phosphate-fluoride system which tends to maintain uniform fluoride levels with depth (Kramer 1964). The fluoride concentration in lake water ranged between 0.21 and $0.43 \mathrm{mg} / \mathrm{L}$ with the mean of $0.34 \mathrm{mg} / \mathrm{L}$. The spatial distribution of fluoride contents and it is found that the east-southern and north-western part of lake are having high concentration ranges between 0.37 and $0.43 \mathrm{mg} / \mathrm{L}$ this is due to geological setting and anthropological factor. Most of the water samples are slightly alkaline due to presence of carbonates and bicarbonate. The bicarbonate concentration in lake water ranged between 50.15 and $146.29 \mathrm{mg} / \mathrm{L}$ with the mean of $82.11 \mathrm{mg} / \mathrm{L}$. The distribution of bicarbonate contents and it is found that the central part of lake is having high concentration. The major source of bicarbonate are the carbonate rocks containing calcite $\left(\mathrm{CaCO}_{3}\right)$ and dolomite $\left(\mathrm{CaMg}\left(\mathrm{CO}_{3}\right)_{2}\right)$. Calcium $(\mathrm{Ca})$ and
Magnesium $(\mathrm{Mg})$ can also be supplied from Ca-silicates and $\mathrm{Mg}$-silicates.

\section{Hydrochemical facies}

The Piper diagram is used to infer hydrogeochemical facies. These plots include two triangles, one for plotting cations and the other for plotting anions. The cation and anion fields are combined to show a single point in a diamond-shaped field, from which inference is drawn on the basis of hydrogeochemical facies concept. Facies are recognizable parts of different characters belonging to any genetically related system. Hydrochemical facies are distinct zones that possess cation and anion concentration categories. The hydrochemical facies of the lake water quality was studied and it was found that the cationic species $\mathrm{Ca}$, and $\mathrm{Mg}$ and anionic species as chloride and sulphate to be dominant in the lake. The dominant water facies in the lake is $\mathrm{Mg}_{-} \mathrm{SO}_{4}$, however, the subdivision of diamond shape in piper trilinear diagram suggests the major water type followed by $\mathrm{Mg}-\mathrm{SO}_{4}$ is $\mathrm{Ca}-\mathrm{Cl}_{2}$ type. Thus, water sample belongs to Quaternary (geology) in the Piper diagram (Fig. 5) shows that these samples are

\section{Piper Diagram}

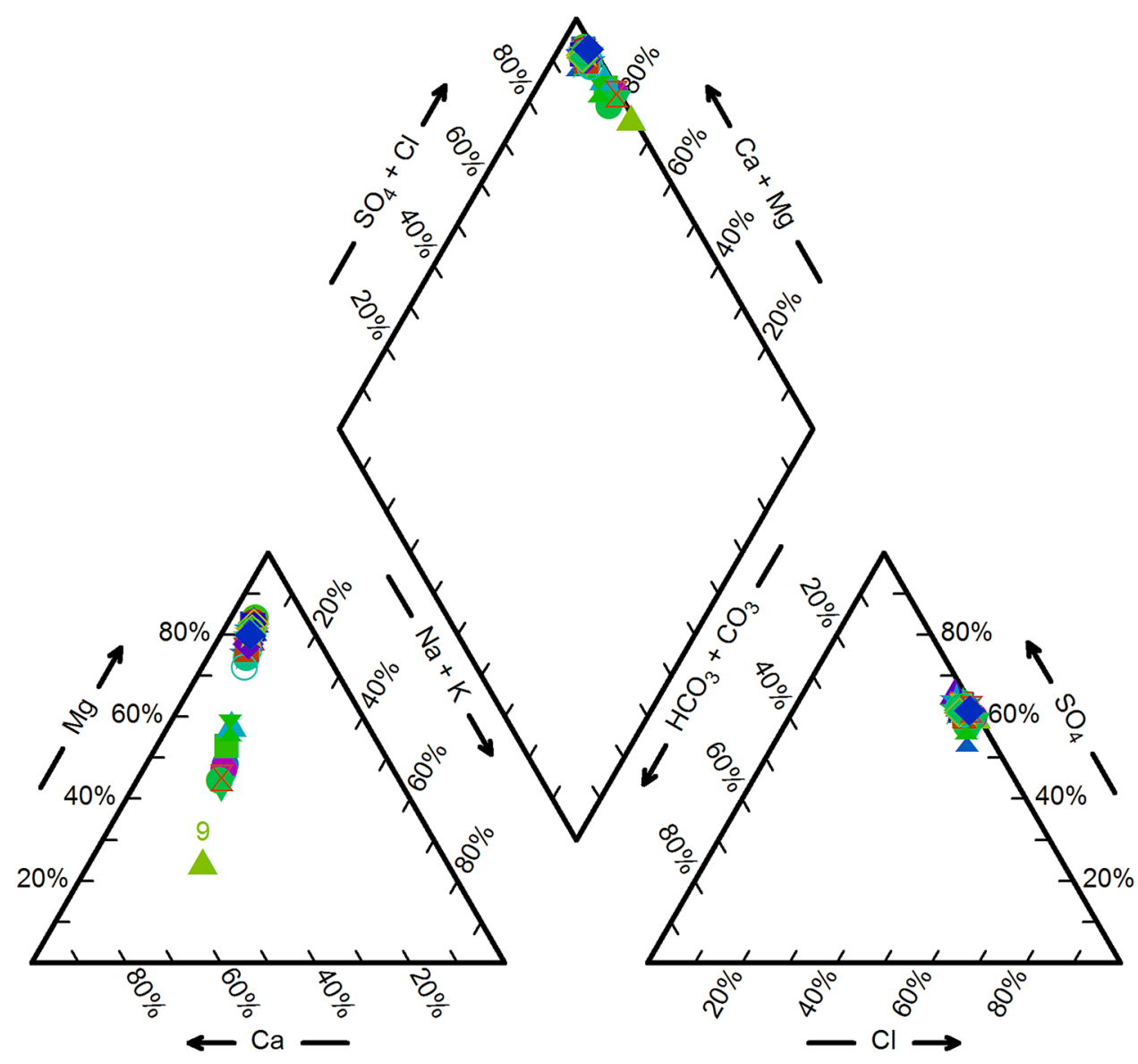

Fig. 5 Piper diagram area 
characterized by the dominance of $\mathrm{Cl}+\mathrm{SO}_{4}$ over $\mathrm{Ca}+\mathrm{Mg}$. The piper trilinear plot (Piper 1944) suggests the increase of $\mathrm{Ca}$ and $\mathrm{SO}_{4}$ contents is attributed to dissolution of gypsum and anhydrite which are commonly found in the quaternary formations of Wadi. The water type indicates the impact of arid climate as the water is mainly enriched in $\mathrm{SO}_{4}$ and $\mathrm{Cl}$. Ion exchange, dissolution of calcite, semiarid climate, alkaline condition and weathering are responsible for high concentration of ions exceeding the desirable limit of the study area.

\section{Conclusion}

This study focuses to assess the levels of certain significant geophysical and chemical water quality parameters and geospatial techniques an integrated scheme for mapping water quality of Al-Saad Lake, Abha. The study's main objective was to assess the hydro-geochemical properties of lake water quality using geospatial and geostatistical approach. Currently, three tools are used for the assessment of lake water quality: (a) water quality monitoring by in situ sampling (b) geospatial analysis and (c) geostatistical modelling. The information derived with each of these tools is of a different nature. Geoinformation technology gives full spatial information of a limited number of parameters. Sampling and experiments of lake water has been carried out with the aim of characterizing the main physico-chemical parameters, such as DO, EC, TDS, $\mathrm{Mg}^{2+}, \mathrm{Ca}^{2+}, \mathrm{Na}^{+}, \mathrm{K}^{+}, \mathrm{SO}_{4}{ }^{2-}, \mathrm{Cl}^{-}, \mathrm{HCO}_{3}$, $\mathrm{NO}_{3}{ }^{-}$and $\mathrm{F}^{-}$concentration. The ordinary kriging $(\mathrm{OK})$ method was used to produce the spatial patterns of water quality. The Result of DO (mean $5.38 \mathrm{mg} / \mathrm{L}$ ) trend in Al-Saad Lake is not very encouraging as majority of the lake area is under DO stress or marginally above it. So, proper management strategies are needed to be formulated to protect flora and fauna of the lake. Furthermore, the chemical analysis results show the abundance of the major cations in the order $\mathrm{Mg}^{2+}>\mathrm{Ca}^{2+}>\mathrm{Na}^{+}>\mathrm{K}^{+}$, whereas the abundance of anions are in the order $\mathrm{SO}_{4}{ }^{2-}>\mathrm{Cl}^{-}>\mathrm{HCO}_{3}>\mathrm{NO}_{3}{ }^{-}>\mathrm{F}^{-}$. The result obtained in this investigation inferred that the cations in water i.e. sodium and iron are within the permissible limits but magnesium and potassium have exceeded the permissible limit. Whereas, anions such as nitrate and fluoride are within the permissible range but chloride and Sulphate have exceeded the permissible limits. The concentration of cation, $\mathrm{Mg}$ and $\mathrm{K}$ in the lake water has exceeded the desirable range. This may be due to weathering and transported from rocks and particularly from sulphate deposits such as gypsum and anhydride and subsequently ends up in water. The concentration of anion, $\mathrm{SO}_{4}$ and $\mathrm{Cl}$ are above the desirable limit. The major source of bicarbonate are the carbonate rocks containing calcite $\left(\mathrm{CaCO}_{3}\right)$ and dolomite $\left(\mathrm{CaMg}\left(\mathrm{CO}_{3}\right)_{2}\right), \mathrm{Ca}$ and $\mathrm{Mg}$ can also be transported from $\mathrm{Ca}$-silicates and $\mathrm{Mg}$-silicates.
The linear correlation coefficient of $\mathrm{Ca}$ with examined water samples, it was found that the variables between calcium and $\mathrm{Na} / \mathrm{K}$ has a very high negative correlation of $R^{2}$ value $=0.85$ this is due to the geological formation of surrounding area such as shale, siltstone and carbonaceous rocks and indicating the dominance of ion-exchange process. The piper trilinear plot suggests the increase of $\mathrm{Ca}$ and $\mathrm{SO}_{4}$ contents is attributed to dissolution of gypsum and anhydrite which are commonly found in the quaternary formations of Wadi. The water type indicates the impact of semi-arid climate as the water is mainly enriched in $\mathrm{SO}_{4}$ and $\mathrm{Cl}$. Ion exchange, dissolution of calcite, semi-arid climate, alkaline condition and weathering are responsible for high concentration of ions exceeding the desirable limit of the study area. The information obtained from this study may, therefore, be used as reference values for assessing the possible environmental impacts of future developments around the lake.

Acknowledgements The author wish to acknowledge the financial support by Deanship of Scientific Research, King Khalid University, KSA; Project Code 74/2012-13. I would like to express my thanks to the Dean, College of Engineering, King Khalid University for their help and support.

Open Access This article is distributed under the terms of the Creative Commons Attribution 4.0 International License (http:// creativecommons.org/licenses/by/4.0/), which permits unrestricted use, distribution, and reproduction in any medium, provided you give appropriate credit to the original author(s) and the source, provide a link to the Creative Commons license, and indicate if changes were made.

\section{References}

Abulfatih HA (1981) Wild plants of Abha and its surroundings. Proc Saudi Bio Soc 5:143-159

Akujieze CN, Coker SJ, Oteze GE (2003) Groundwater in Nigeria-a millennium experience-distribution, practice, problems and solutions. Hydrogeol J 1:259-274

Allewijn R, Kokke JMM, Dekker AG, Vos RJ (1995) Remote sensing and water quality in the Netherlands. In: Askne J (ed) Sensors and environmental applications of remote sensing. A. A. Balkema, Rotterdam, pp 273-280

Al-Otaibi EL, Zaki MSA (2012) Quality assessment of traditional water resources in Khamish Mushayet city, Abha metropolitan, Aseer Province, Saudi Arabia. Int J Water Resour Environ Eng 4(7):227-240

APHA (2005) Standard methods for the examination of water and waste water, 21st edn. American Public Health Association, New York

Arenz RF, Lewis WM, Saunders JF (1996) Determination of chlorophyll and dissolved organic carbon from reflectance data for colorado reservoirs. Int J Remote Sens 17:1547-1566

Blaakman EJ, Hut RMG, Lammens EHRR, Buiteveld H (1995) Integration of remote sensing in ECOSYS. Report no. 95.011 (in Dutch). RIZA, Leiystad 
Bureau of Indian Standards (BIS) (2003) Bureau of Indian Standards Specification for drinking water. IS: 10500:91 revised 2003, Bureau of Indian Standards, New Delhi

Burgis MJ, Mavuti KM (1987) The Gregory Rift African wetlands and shallow water bodies, Dircetory. Coll. "Travaux et Documents". O.R.S.T.O.M., Paris 211, pp 331-358

Castrignano A, Cherubini C, Gaisi Consetta I, Musci F, Pastore N (2007) Multivariate geostatistical and natural attenuation model approach for remediation of chlorinated compounds. WSEAS Trans Environ Dev 3(5):90-98

Chatterjee T (1996) The Kolleru lake conservation and management project. A community driven lake conservation Plan. In: conservation and management of lakes/reservoirs in India. International Lake environment committee, foundation (ILEC). Chem Geol 95:36-62

Chin DA (2000) Water-resources engineering. Prentice-Hall Inc., Upper Saddle River, pp 585-635

Commoner B (1971) The closing circle. Knopf, New York

Dagaonkar A, Saksena DN (1992) Physico-chemical and biological characterization of a temple tank, Kaisa Sagar, Gwalior, Madhya Pradesh. Hydrobiol J 8(1):11-19

Dewidar K, Khedr A (2001) Water quality assessment with simultaneous Landsat-5 TM at Manzala Lagoon, Egypt. Hydrobiologia 457:49-58

Friedl G, Teodoru C, Wehrli B (2004) Is the Iron Gate I reservoir on the Danube River a sink for dissolved silica? Biogeochemistry 68:21-32

Goel PK, Sharma KP (1996) Environmental guidelines and standards in India. Technoscience Publishers, Jaipur, pp 1-318

G.C.C.S (Gulf Cooperation Council Standards) (1993) Unbottled drinking water standards, Standardization and Metrology Organization for the Gulf Cooperation Council Countries \# GS 149/193, Riyadh, Saudi Arabia

Klein L (1973) River pollution-causes and effects, vol 2. Butterworth and Co., Ltd., London

Kramer PJ (1964) The role of water in wood formation. In: Zimmermam MH (ed) The formation of wood in forest trees. Academic Press, New York, pp 519-532

Lillesand TM, Kiefer RW (1994) Remote sensing and image interpretation, 3rd edn. Wiley, New York

Mallick J, Alashker Y, Shams Al-Deen M, Ahmed M, Hasan MA (2013) Risk assessment of soil erosion in semi-arid mountainous watershed in Saudi Arabia by RUSLE model coupled with remote sensing and GIS. Geocarto Int. doi:10.1080/10106049. 2013.868044

Mallick J, Hussein AW, Rahman A, Ahmed M, Khan RA (2015) Spatial variability of soil erodibility and its correlation with soil properties in semi-arid mountainous watershed, Saudi Arabia. Geocarto Int. doi:10.1080/10106049.2015.1073368
Marsaglia G, Tsand WW, Wang J (2003) Evaluating Kolmogorov's distribution. J Stat Softw 8(1-4):2003

Moor NW (1984) The ecological impact of pollution. IUCN Publ New Ser 17(1):80-81

Njenga JW (2004) Comparative studies of water chemistry of four tropical lakes in Kenya and India. Asian J Water Environ Pollut 1, 2:87-97

Piper AM (1944) A graphical procedure in the geochemical interpretation of water analysis. Am Geophys Union Trans 25:914-928

Punmia BC, Jain AK (1998) Wastewater engineering. Laxmi Publications (P) Ltd, New Delhi

Ravi KP, Mohammad AM, Somashekar RK (2013) Water quality index to determine the surface water quality of Sankey tank and Mallathalli lake, Bangalore urban district, Karnataka, India. Appl Water Sci 3:247-261

REWANET (1994) Ease 1. Inventarisation of applications of remote sensing in water quality, Netherlands, Remote Sensing Board Report 94-23, 4.1-5.5, Delft, The Netherlands

Ruiz-Azuara P (1995) Multitemporal analysis of "simultaneous" Landsat imagery (MSS and TM) for monitoring primary production in a small tropical coastal lagoon. Photogramm Eng Remote Sens 61:877

Sajjad-Mustafa Nasir D (1999) A geochemical survey and water quality modelling study of the lake st. Clair water system. MSc. Thesis at the University of Windsor, Ontario

Saxton KE, Rawls WJ, Romberger JS, Papendick RI (1986) Estimating generalized soil water characteristics from texture. Soil Sci Soc Am J 50:1031-1036

Singh CK, Kumari R, Singh N, Mallick J, Saumitra M (2012) Fluoride enrichment in aquifers of Thar Desert: controlling factors and its geochemical modeling. Hydrological Processes, Wiley, New York. doi:10.1002/hyp.9245 (Accepted Article)

Toi AC, Van Meer AJ, Hoek SB, Leeuw AJ (1992) Integration of remote sensing with water quality monitoring network for lakes IJssel and Markermeer on behalf of network analysis and optimization. Netherlands, Remote Sensing Board Report 92-21 (in Dutch)

Venkatasubramani R, Meenambal T (2007) Study of the sub surface water quality in Mettupalayam taluk of Coimbatore district, Tamil Nadu. Nat Environ Pollut Tech 6:307-310

Vincent RK, Qin X, Michael R, McKay L, Miner J, Czajkowski K, Sayino J, Bridgeman T (2004) Phycocyanin detection form LANDSAT TM data for mapping cyanobacterial blooms in Lake Erie. Remote Sens Environ 89:381-392

Vos RJ (1995) "RESTWAQ": applications of remote sensing to water quality modelling. Delft Hydraulics Report T1083/T1479, Delft, The Netherlands 